\title{
Perbandingan Metode KNN, Decision Tree, dan Naïve Bayes Terhadap Analisis Sentimen Pengguna Layanan BPJS
}

\author{
Rani Puspita ${ }^{1}$, Agus Widodo ${ }^{2}$ \\ Computer Science Department, School of Computer Science, Bina Nusantara University, Jakarta, \\ Indonesia 11480 \\ e-mail: ${ }^{1}$ rani.puspita@ $@$ binus.ac.id, ${ }^{2}$ ag45wd@binus.ac.id
}

Submitted Date: November $09^{\text {th }}, 2020$

Revised Date: January $04^{\text {th }}, 2021$
Reviewed Date: December $30^{\text {th }}, 2020$

Accepted Date: January $08^{\text {th }}, 2021$

\begin{abstract}
BPJS is really helpful because one of its goal is to provide good service for the member in terms of healthiness. But, when there's many people using the service, then it will cause more pros and contras. Therefore, researcher will be doing sentiment analysis in the field of data mining towards bpjs users on social media Twitter as much as 1000 data that later will be filtered to be 903 data because there are some data that has been duplicated. Researchers used the KNN, Decision Tree, and Naïve Bayes methods to compare the accuracy of the three methods. Researchers used the RapidMiner version 9.7.2 tools. The results showed that the sentiment analysis of Twitter data on BPJS services using the KNN method reached an accuracy level of $95.58 \%$ with class precision for pred. negative is $45.00 \%$, pred. positive is $0.00 \%$, and pred. neutral is $96.83 \%$. Then the Decision Tree method the accuracy rate reaches $96.13 \%$ with the precision class for pred. negative is $55.00 \%$, pred. positive is $0.00 \%$, and pred. neutral is $97.28 \%$. And the last one is the Naïve Bayes method which achieves $89.14 \%$ accuracy with precision class for pred. negative is $16.67 \%$, pred. positive was $1.64 \%$, and pred. neutral is $98.40 \%$.
\end{abstract}

Keywords: Sentiment Analysis; BPJS; Twitter; Data Mining

\begin{abstract}
Abstrak
BPJS sangat membantu dalam hal kesehatan. Namun ketika ada banyak orang yang menggunakan layanan tersebut, maka akan banyak pula pro dan kontra yang didapatkan. Oleh karena itu peneliti melakukan analisis sentimen dalam bidang data mining terhadap pengguna BPJS pada media sosial Twitter sebanyak 1000 data yang kemudian difiltering menjadi 903 data dikarenakan adanya data yang terduplikat. Penulis menggunakan metode KNN, Decision Tree, dan Naïve Bayes untuk memperbandingkan tingkat akurasi dari ketiga metode tersebut. Peneliti menggunakan tools RapidMiner versi 9.7.2. Hasil penelitian menunjukan bahwa analisis sentimen terhadap data Twitter terhadap layanan BPJS dengan menggunakan metode KNN mencapai tingkat akurasi $95.58 \%$ dengan class precision untuk pred. negative adalah $45.00 \%$, pred. positive adalah $0.00 \%$, dan pred. neutral adalah $96.83 \%$. Lalu pada metode Decision Tree tingkat akurasinya mencapai $96.13 \%$ dengan class precision untuk pred. negative adalah $55.00 \%$, pred. positive adalah $0.00 \%$, dan pred. neutral adalah $97.28 \%$. Dan yang terakhir adalah metode Naïve Bayes yang mencapai akurasi $89.14 \%$ dengan class precision untuk pred. negative adalah $16.67 \%$, pred. positive adalah $1.64 \%$, dan pred. neutral adalah $98.40 \%$.
\end{abstract}

Keywords: Analisis Sentimen; BPJS; Twitter; Data Mining

\section{Pendahuluan}

Badan Penyelenggara Jaminan Sosial atau BPJS adalah badan hukum yang dibuat untuk dapat menyelenggarakan program jaminan untuk kesehatan. (Linda, Haskas, \& Kadrianti, 2020). Pada dasarnya BPJS sangatlah membantu karena salah satu tujuan dari BPJS itu sendiri adalah untuk memberikan layanan yang baik bagi peserta dalam hal kesehatan. Tetapi semakin banyak penduduk yang menggunakan layanan tersebut, semakin banyak pula pro dan kontra dari masyarakat Indonesia. Mulai dari yang pro karena 
merasa tidak terbebani perihal biaya jika berobat ke suatu RS ataupun yang kontra karena merasa tidak terlalu diprioritaskan.

Maka dari itu perlu diketahui opini dari masyarakat Indonesia mengenai layanan dari BPJS. Biasanya masyarakat mengemukakan pendapatnya melalui sosial media. Salah satu aplikasi yang sering digunakan masyarakat Indonesia adalah Twitter. Twitter adalah sebuah platform untuk menyampaikan opini atau pendapat seseorang. Pertumbuhan pengguna Twitter di Indonesia sangat pesat dan menduduki peringkat 5 di dunia. (Utami, 2020). Twitter banyak digunakan orang untuk menyampaikan keluh kesahnya mulai dari keluh kesah mengenai kehidupan sehari-hari ataupun keluh kesah terhadap layanan yang diberikan baik dari pemerintah atau bidang lainnya.

Oleh karena itu sangat efisien jika menggunakan Twitter sebagai media untuk mengambil data mengenai keluhan masyarakat Indonesia terkait layanan BPJS.

Berdasarkan studi literatur yang peneliti amati, penelitian mengenai Sentimen Analisis yang dilakukan oleh Denty Welmin dkk tentang: "Anaysis of User Sentiment of Twitter to RUU KUHP". (Cahyaningrum et al., 2020). Dalam penelitian ini dapat diketahui bahwa peneliti menggunakan $\mathrm{R}$ studio untuk bahasa pemrograman. Akan tetapi penelitian ini tidak menjelaskan secara spesifik metode apa yang digunakan dalam penelitian tersebut.

Penelitian lainnya yang dilakukan oleh Retno Sari tentang Analisis Sentimen dapat diketahui bahwa peneliti menggunakan metode KNN. Akan tetapi tidak dijelaskan menggunakan tools apa dalam penelitiannya. Dan dalam penelitian ini juga hanya terdapat satu metode yang dilakukan oleh penelitinya. (Sari, 2020)

Dalam penelitian lainnya yang dilakukan oleh Ghulam Asrofi Buntoro tentang Analisis Sentimen (Buntoro, 2017) dapat diketahui bahwa peneliti menggunakan metode SVM. Tetapi tidak dijelaskan tools dalam analisisnya.

Perlu diketahui bahwa sentimen analisis adalah cabang dari data mining. Data Mining merupakan sebuah proses yang dapat mengekstrak informasi sehingga menghasilkan informasi yang sangat berharga. (Nurdin, 2017). Dengan kata lain dapat juga dikatakan bahwa data mining merupakan proses untuk mencari informasi mengenai teknik tertentu. Teknik dan metode dalam data mining sangat banyak. Oleh karena itu, dalam pemilihan teknik atau algoritma yang tepat akan sangat bergantung pada tujuan yang diinginkan.

Dengan betitu, peneliti menggunakan tiga metode dalam analisis sentimen untuk memperbandingkan tingkat akurasi dari ketiga metode tersebut diantaranya adalah metode KNN, Decision Tree dan Naïve Bayes.

Algoritma KNN adalah salah satu algoritma yang sudah popular. KNN ini termasuk ke dalam grup instance-based learning. Metode KNN merupakan teknik lazy learning. (Cahyanti, Rahmayani, \& Ainy, 2020). Maksudnya adalah metode ini digunakan dalam klasifikasi data yang jaraknya dekat. Ada juga yang berpendapat bahwa algoritma KNN adalah algoritma pembelajaran yang banyak digunakan dalam sistem cyber-fisiksosial (CPSS) untuk menganalisis dan menambang data (main data). (Zhang, Chen, Liu, \& Xi, 2020).

Selain metode KNN, peneliti juga menggunakan metode Decision Tree. Algoritma Tree biasa dipakai untuk pengenalan pola statistik. (Sarimuddin et al., 2020). Decision Tree terbuat dari tiga simpul yaitu leaf, lalu terdiri juga dari simpul root yang merupakan titik awal dari suatu decision tree, dan yang terakhir adalah simpul perantara yang berhubungan dengan suatu pengujian.

Selain menggunakan metode $\mathrm{KNN}$ dan Decision Tree, peneliti juga menggunakan metode Naïve Bayes. Naïve Bayes adalah metode machine learning untuk probabilitas. Dalam kata lain, Naïve Bayes merupakan metode untuk klasifikasi text dengan kecepatan pemrosesan yang tinggi jika dalam data besar. (Fitriyyah, Safriadi, \& Pratama, 2019). Ada juga yang berpendapat bahwa Naïve Bayes adalah metode yang digunakan untuk prediksi karena mengandung probabilistik sederhana yang diterapkan pada teorema bayes dengan ketergantungan yang kuat. (Sinaga, Sawaluddin, \& Suwilo, 2020).

Atas dasar latar belakang tersebut, maka dilakukannya penelitian ini untuk ke tiga metode tersebut dengan mengintegrasikan Twitter sebagai platform untuk peneliti melakukan pengolahan data untuk mengetahui analisis sentimen terhadap layanan BPJS dengan data mining.

Masalah dalam penelitian ini adalah bagaimana cara peneliti mengumpulkan data dari Twitter dan berapa tingkat akurasi dari metode KNN, Decision Tree dan Naïve Bayes.

Selain itu, tujuannya adalah untuk mengetahui cara mengumpulkan data Twitter 
menggunakan RapidMiner dan mengetahui tingkat akurasi dari ketiga metode yang diteliti.

Penelitian ini merupakan ide yang penulis buat sendiri sebagai bahan penelitian untuk menganalisis sentimen terhadap layanan BPJS dengan cara mengumpulkan data dari Twitter dan menganalisis data tersebut dengan tools tertentu.

\section{Metodologi}

\subsection{Metode Pengumpulan data}

Metode yang dilakukan oleh penulis adalah sebagai berikut:

a. Studi Literatur

Dalam studi literatur ini, peneliti mempelajari materi terkait penelitian dari referensi yang terpercaya. Setelah itu, peneliti akan mencari informasi yang dibutuhkan dalam penelitian ini. Informasi yang didapatkan akan digunakan dalam penyusunan. Semua pustaka yang dijadikan acuan dapat dilihat pada halaman daftar pustaka.

\section{b. Pengumpulan Data}

Dalam hal ini, data dikumpulkan dari sosial media Twitter. Peneliti menggunakan RapidMiner versi 9.7.2 sebagai alat untuk mengambil data pada Twitter terkait pendapat orang terhadap layanan BPJS. Berikut adalah gambaran cara proses crawling data dari Twitter menggubakan RapidMiner.

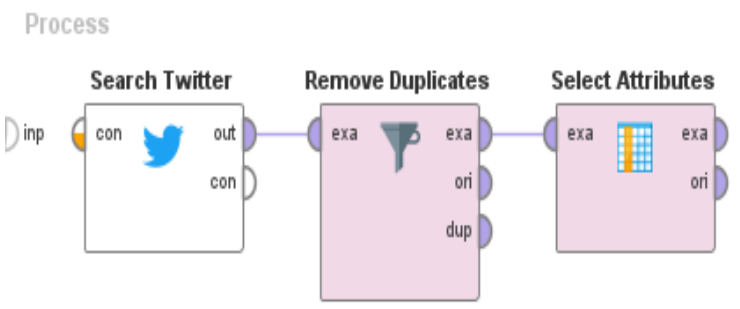

Gambar 1. Proses Crawling Dan Filtering Data

Langkah pertama adalah pengumpulan data atau yang bisa disebut crawling data. Peneliti melakukan crawling data pada sosial media Twitter dengan limit 1000. Kemudian peneliti melakukan proses filtering data dengan cara remove duplicate karena terdapat data yang double. Setelah peneliti melakukan remove duplicate pada data yang terambil double, dapat dihasilkan data akhir yang didapatkan yaitu sebanyak 903 data.

Setelah melakukan proses filtering data dengan cara remove duplicate dilanjutkan dengan dilakukannya select attributes yang bertujuan untuk memilih text pada data.

Dan proses terakhir pada crawling data ini adalah data akan di export dalam bentuk excel dan kemudian dilakukan pelabelan untuk data yang bersifat positif, negatif atau netral.

\subsection{Peralatan Dalam Penelitian}

Peralatan dalam penelitian terbagi menjadi dua. Berikut rincian peralatan penelitian yang digunakan:

a. Perangkat keras:

1. HP Laptop 14s-cf0055TX.

2. RAM 8 GB.

b. Software:

1. OS Windows 10 Pro 64bit.

2. Menggunakan RapidMiner versi 9.7.2.

3. Sistem operasi windows 10 profesional.

4. Microsoft Excel.

\subsection{Hasil Pengumpulan Data}

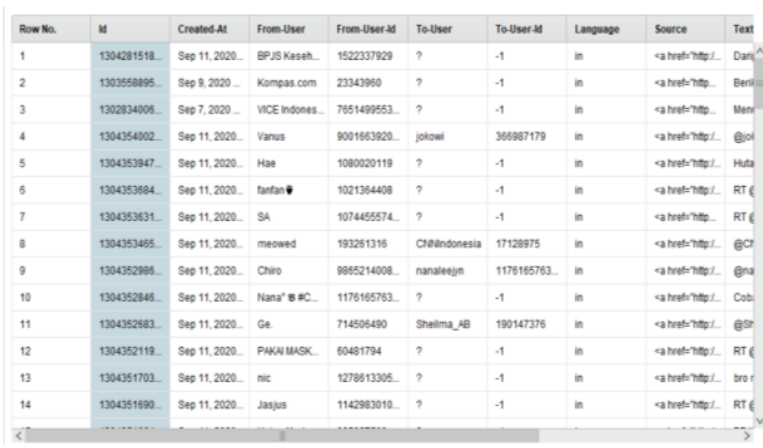

Gambar 2. Tahap Awal Pengumpulan Data Twitter

Pada gambar 2, terdapat language, source, logitude, latitude, text dan lain sebagainya. Karena hanya membutuhkan text, maka peneliti menghilangkan row selain text.

Selain result berupa tabel yang ada pada Gambar 2, terdapat pula hasil atau result yang berbentuk grafik pada Gambar 3.

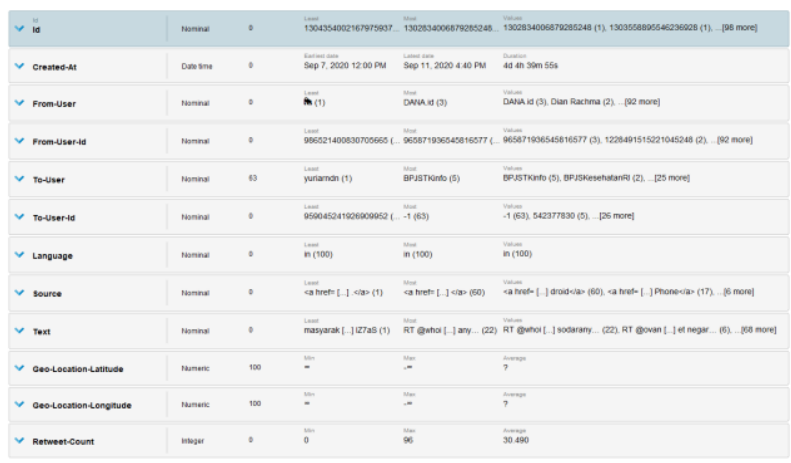

Gambar 3. Grafik Pengumpulan Data 
Gambar 3 adalah hasil dari filtering data. Sehingga hanya tersisa row number, ID, dan isi text.

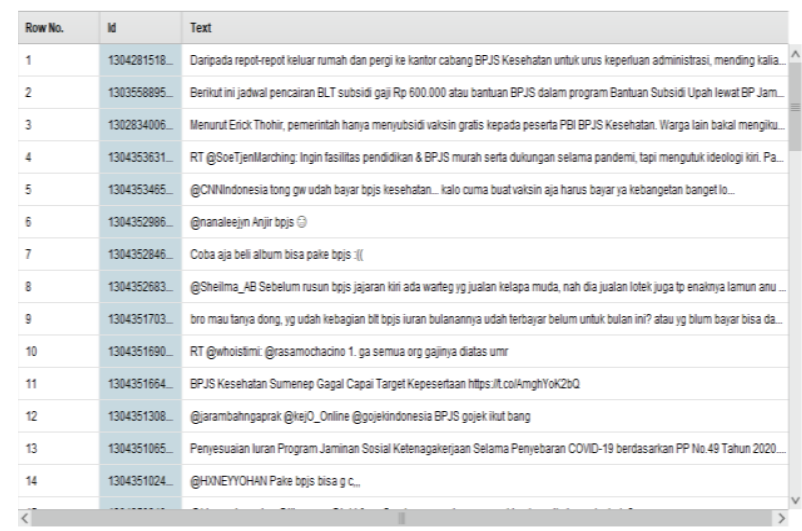

Gambar 4. Hasil Pengumpulan Data Dari Twitter

Gambar 4 adalah contoh dari data yang berhasil di crawling dari Twitter dan yang sudah peneliti hilangkan selain row Text. Sehingga sekarang hanya terdapat Row number berupa ID dan text. Hal ini dikarenakan Row Number dan ID wajib dan tidak bisa dihilangkan.

Selain result berupa tabel yang ada pada Gambar 4, terdapat pula hasil atau result yang berbebtuk grafik pada Gambar 5 .

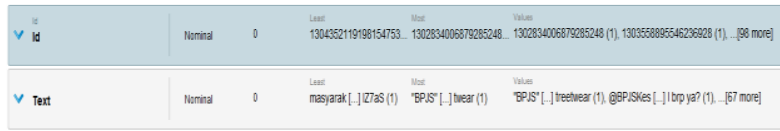

Gambar 5. Grafik Hasil Pengumpulan Data Twitter

\subsection{Preprocessing}

Seperti yang telah dijelaskan sebelumnya, bahwa data yang diperoleh dalam penelitian ini adalah sebanyak 1000 record Tweet mengenai layanan BPJS dari pengumpulan data menggunakan Twitter dengan tools RapidMiner. Untuk mendapatkan data yang baik, maka berikut ini adalah beberapa teknik preprocessing yang peneliti gunakan:

\section{a. Data Validation}

Pada tahap ini, peneleti mengidentifikasi sekaligus menghapus data yang sekiranya tidak digunakan, data non konsisten dan data yang missing.

\section{b. Data Integration dan Transformation}

Pada tahap ini, peneliti meningkatkan akurasi dari metode yang digunakan oleh peneliti. c. Data Size Redution and Dicretization
Pada tahap ini, peneliti merapikan data yang berhasil dikumpulkan dengan cara men-delete yang terduplikat.

\subsubsection{Proses awal}

Pada proses ini dilakukan proses awal terhadap data yang telah dikumpulkan dengan tools RapidMiner. Berikut adalah gambaran cara kerjanya:

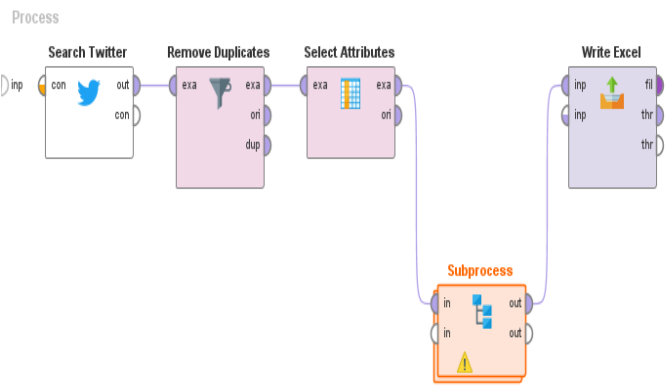

Gambar 6. Proses Awal

Gambar 6 adalah contoh proses awal yang peneliti lakukan pada tools RapidMiner.

Terdapat search Twitter, remove duplicate, replace attributes, sub process, dan write excel.

\subsubsection{Sub Proses}

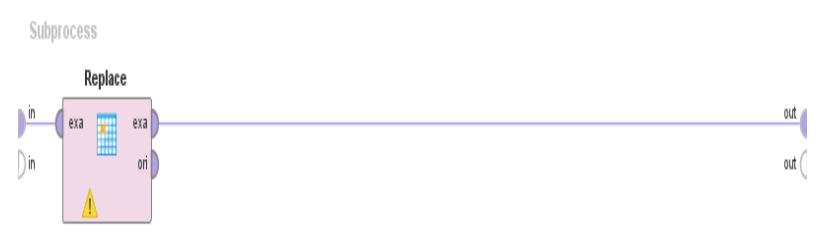

Gambar 7. Sub Proses

Gambar 7 adalah contoh sub process awal yang peneliti lakukan pada tools RapidMiner. Ada action untuk replace, dimana replace bertujuan untuk menghilangkan sesuatu yang tidak akan digunakan seperti tanda hashtag pada text.

\subsection{Proses Cross Validation}

Cross validation ini adalah sebuah action yang peneliti lakukan untuk mencari akurasi dari masing-masing metode dengan membagi data berupa training dan testing. berupa apply model dan performance. 


\subsubsection{Proses Cross Validation KNN}

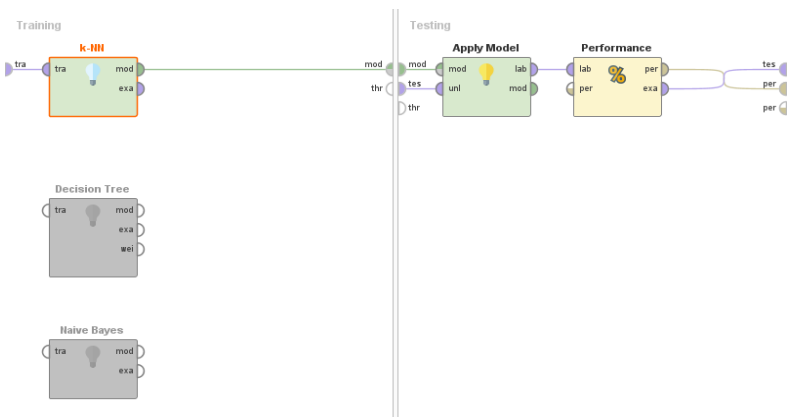

Gambar 8. Proses Cross Validation KNN

Gambar 8 adalah step untuk cross dalam algoritma KNN. Pada kolom data training terdapat action metode KNN. Dan pada kolom data testing terdapat action berupa apply model dan performance. Hal ini bertujuan untuk mengetahui tingkat akurasi data pada metode KNN.

\subsubsection{Proses Cross Validation Decision Tree}

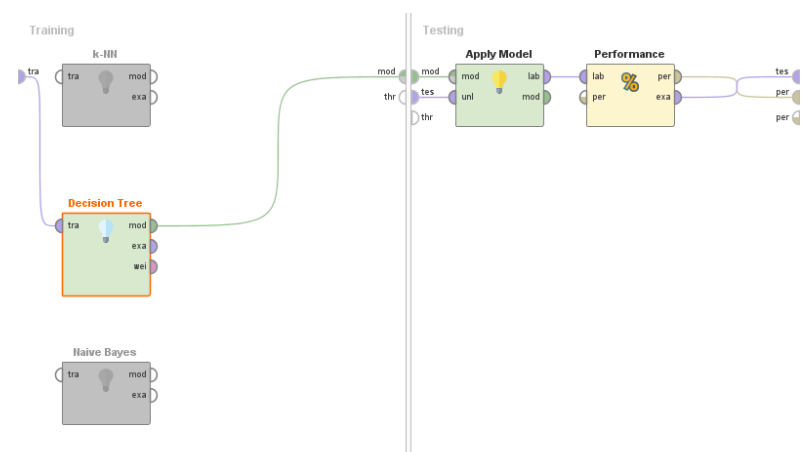

Gambar 9. Proses Cross Validation Decision Tree

Gambar 9 adalah step untuk cross validation dalam algoritma Decision Tree. Pada kolom data training terdapat action metode Decision Tree. Dan pada kolom data testing terdapat action berupa apply model dan performance. Hal ini bertujuan untuk mengetahui tingkat akurasi data pada metode Decision Tree.

\subsubsection{Proses Cross Validation Naïve Bayes}

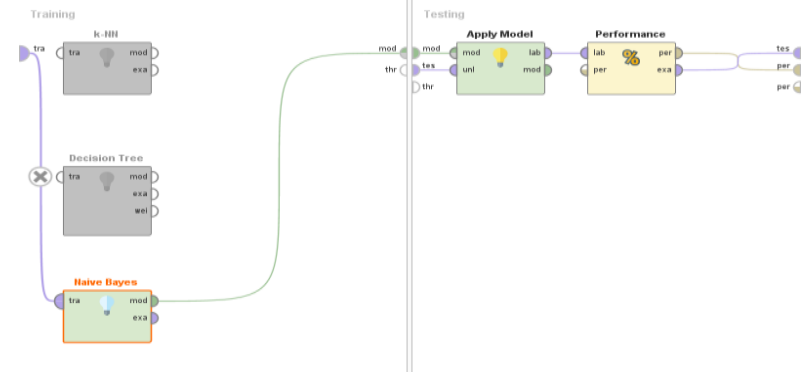

Gambar 10. Proses Cross Validation Naive Bayes
Gambar 10 adalah step untuk cross validation dalan algoritma Naïve Bayes. Pada kolom data training terdapat action metode Naive Bayes. Pada data testing terdapat apply model dan performance. Hal ini bertujuan untuk mengetahui tingkat akurasi data pada metode Naive Bayes.

\subsection{Alur Penelitian}

Di bawah ini merupakan alur penelitian dalam jurnal yang peneliti buat:

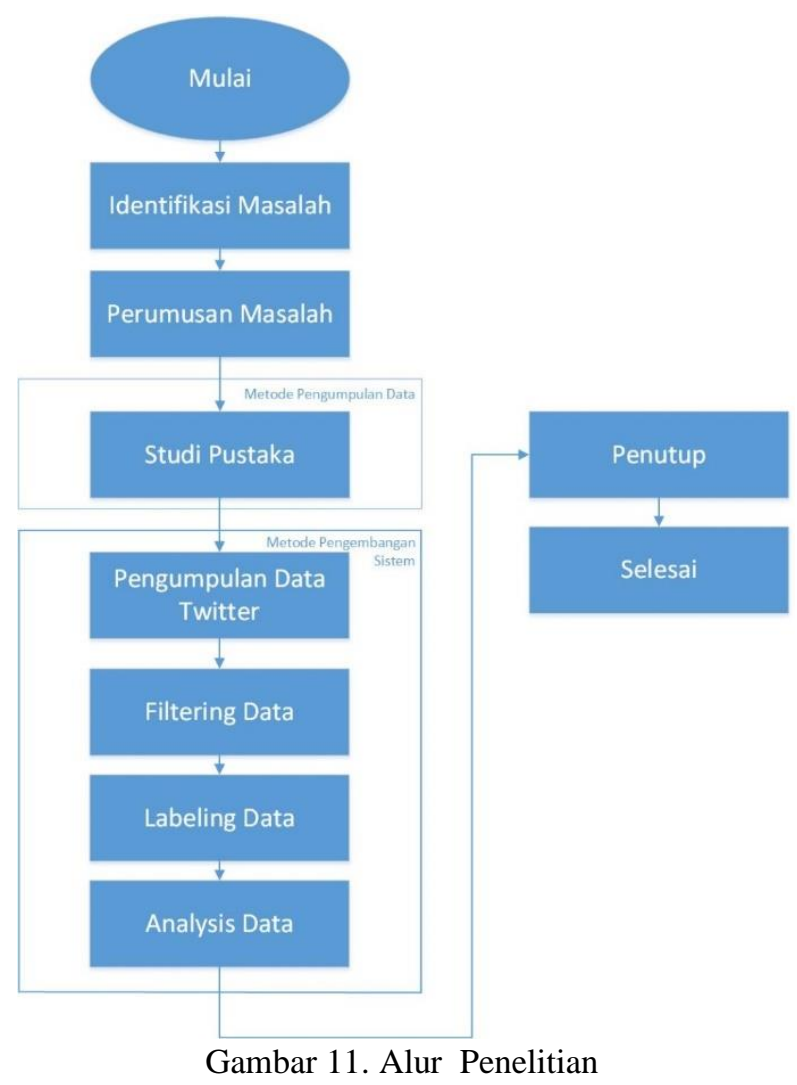

Berikut ini adalah penjelasan mengenai alur penelitian:

a. Identikasi Masalah

Pada tahapan ini, peneliti mengidentifikasi masalah yang ingin diuji dalam penelitian ini.

b. Rumusan Masalah

Pada tahapan ini, peneliti melakukan perumusan masalah. Dalam hal ini, masalah yang ingin diuji adalah bagaimana cara mengumpulkan data melalui Twitter dengan tools RapidMiner dan berapa tingkat akurasi dari metode KNN, Decision Tree, dan Naïve Bayes.

c. Metode Pengumpulan Data

Pada tahap ini, data yang dimaksud adalah seperti pengertian-pengertian atau penjelasan teoritis mengenai apa itu data mining, apa itu 
metode KNN, apa itu metode Decision Tree, dan apa itu metode Naïve bayes. Maka dari itu peneliti hanya menggunakan studi pustaka pada tahapan ini. Studi pustaka berupa jurnal nasional dan internasional.

d. Pengumpulan Data Twitter

Pada tahapan ini sering disebut dengan crawling data. Data yang akan dikumpulkan adalah sebanyak 1000 data. Proses ini tidak memakan waktu yang lama. Tergantung Device yang digunakan untuk mengambil data. Dan pada tahap ini harus sudah mempunyai akun Twitter untuk mendapatkan akses token yang akan diinput pada tools RapidMiner.

e. Filtering Data

Pada tahapan ini, peneliti melakukan proses filtering karena terdapat data yang double. Sehingga data yang tadinya 1000 sekarang hanya 903 data yang tersisa.

f. Labeling Data

Pada tahapan ini, peneliti melakukan proses Labeling Data untuk mengetahui sifat dari text yang sudah dikumpulkan. Labeling ini terdapat label positif, negatif, dan netral. Lalu peneliti dapat mengatur untuk memberi warna pada label untuk memudahkan.

g. Analysis Data

Pada tahapan ini, peneliti menganalisis akurasi dari ketiga metode yang digunakan.

\section{Hasil dan Pembahasan}

Hasil dan pembahasan mengenai sentimen analisis terhadap layanan BPJS dengan metode KNN, Decision Tree, dan Naïve Bayes yang peneliti olah menggunakan RapidMiner maka contoh crawling data yang sudah dilakukan labeling dan nilai akurasi dari setiap metode, dan dijelaskan pada subbab berikutnya.

\subsection{Labeling}

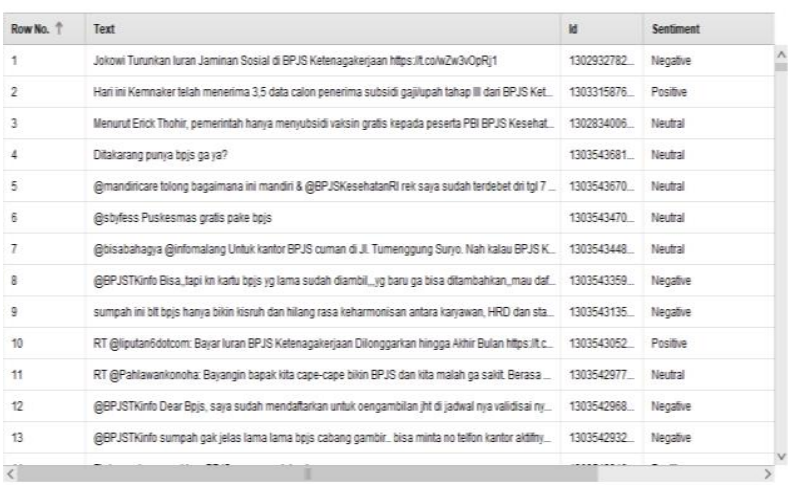

Gambar 12. Labeling Data
Gambar 12 adalah contoh dari data yang sudah dilabeling. Jika sebelumnya hanya berupa row, ID, dan text. Maka pada tahap ini akan ada satu tabel lagi yang bernama sentiment. Label ini digunakan untuk mengetahui isi dari text yang sudah di crawling tersebut bersifat apa. Terdapat tiga sifat data yaitu positif, negatif, dan netral.

Selain result dalam bentuk tabel, kita juga dapat melihat result dalam bentuk grafik.

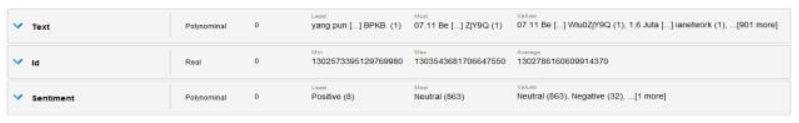

Gambar 13. Grafik Labeling Data

\subsection{Hasil Accuracy Algoritma KNN}

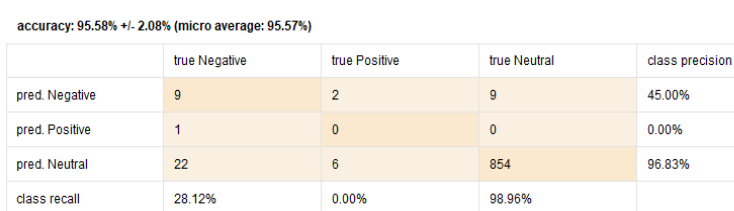

Gambar 14. Hasil Accuracy KNN

Hasil pada metode Decision Tree menyatakan bahwa tingkat akurasi pada metode ini sebesar adalah $95.58 \%$. Dimana class precision untuk pred. negative adalah $45.00 \%$, pred positive adalah $0.00 \%$, dan pred. neutral adalah $96.83 \%$.

Lalu juga terdapat plot view dari algoritma ini. Berikut gambarnya:

confusion Matrix (x. true class, y: pred. class, $z$ counters)

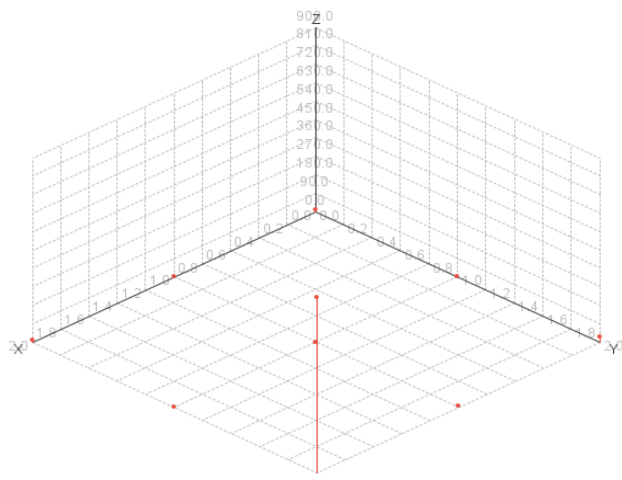

Gambar 15. Plot View Metode KNN

Selain tabel, terdapat juga performance vector untuk metode $\mathrm{KNN}$. 


\section{PerformanceVector}

Performancevector:

accuracy: $95.58 \%+/-2.08 \%$ (micro average: $95.57 \%$ )

ConfusionMatrix:

True: Negative Positive Neutral

Negative: 9

Positive: 10

Neutral: $22 \quad 6 \quad 854$

kappa: $0.269+/-0.324$ (micro average: 0.326 )

ConfusionMatrix:

True: Negative Positive Neutral

Negative:

Positive

Positive:

Neutral:

Gambar 16. Performance Vector Metode KNN

Performance vector sendiri merupakan bentuk deskripsi dari tabel hasil analisis. Hanya saya terdapat tambahan seperti kappa pada performance vector metode $\mathrm{KNN}$ ini.

\subsection{Hasil Accuracy Algoritma Decision Tree}

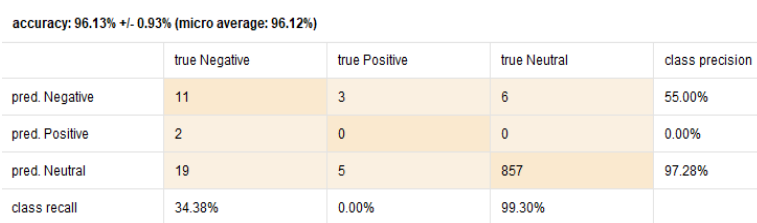

Gambar 17. Hasil Accuracy Decision Tree

Hasil pada metode KNN menyatakan bahwa tingkat akurasi pada metode ini adalah $96.13 \%$. Dimana class precision untuk pred. negative adalah $55.00 \%$, pred. positive adalah $0.00 \%$, dan pred. neutral adalah $97.28 \%$.

Selain itu juga terdapat performance vector dari metode Decision Tree. Lalu juga terdapat plot view dari algoritma ini.

Confusion Matrix (x. true class, y. pred. class, $z$ counters)

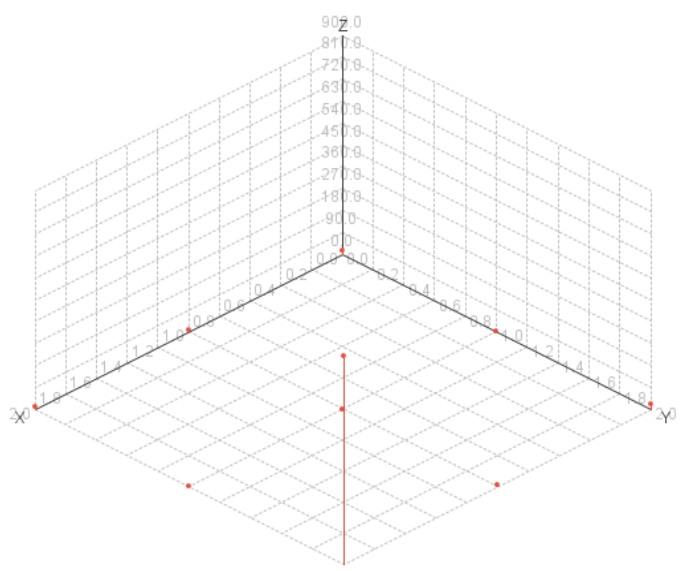

Gambar 18. Plot View Metode Decision Tree

\section{PerformanceVector}

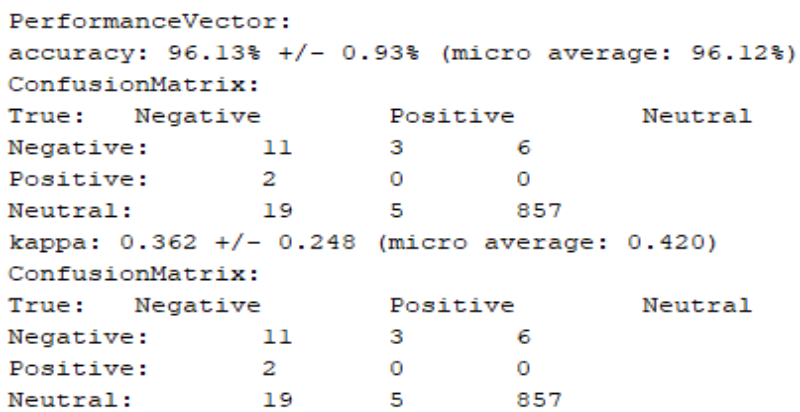

Gambar 19. Performance Vector Metode Decision Tree

Performance vector sendiri merupakan bentuk deskripsi dari tabel hasil analisis. Hanya saya terdapat tambahan seperti kappa pada performance vector metode Decision Tree ini.

\subsection{Hasil Accuracy Algoritma Naïve Bayes}

\begin{tabular}{|l|l|l|l|l|}
\hline \multicolumn{2}{|c|}{ accuracy: $89.14 \%++.2 .78 \%$ (micro average: $89.15 \%$ ) } & & \\
\hline & true Negative & true Positive & true Neutral & class precision \\
\hline pred. Negative & 5 & 5 & 20 & $16.67 \%$ \\
\hline pred. Positive & 16 & 1 & 44 & $1.64 \%$ \\
\hline pred. Neutral & 11 & 2 & 799 & $98.40 \%$ \\
\hline class recall & $15.62 \%$ & $12.50 \%$ & $92.58 \%$ & \\
\hline
\end{tabular}

Gambar 20. Hasil Accuracy Naïve Bayes

Hasil pada metode Naïve Bayes menyatakan bahwa tingkat akurasi pada metode adalah $89.14 \%$. Dimana class precision untuk pred. negative adalah $16.67 \%$, pred positive adalah $1.64 \%$, dan pred. neutral adalah $98.40 \%$.

Selain itu juga terdapat performance vector untuk metode Naïve Bayes. Lalu juga terdapat plot view dari algoritma ini.

Confusion Matrix (x. true class, y. pred. class, $z$ counters)

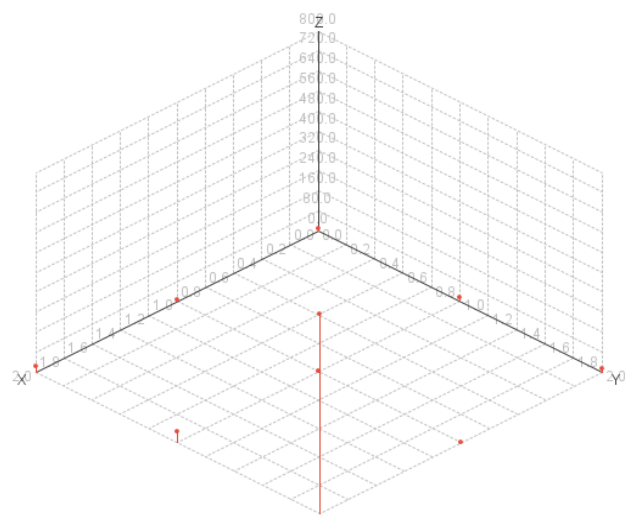

Gambar 21. Plot View Metode Naive Bayes 


\section{PerformanceVector}

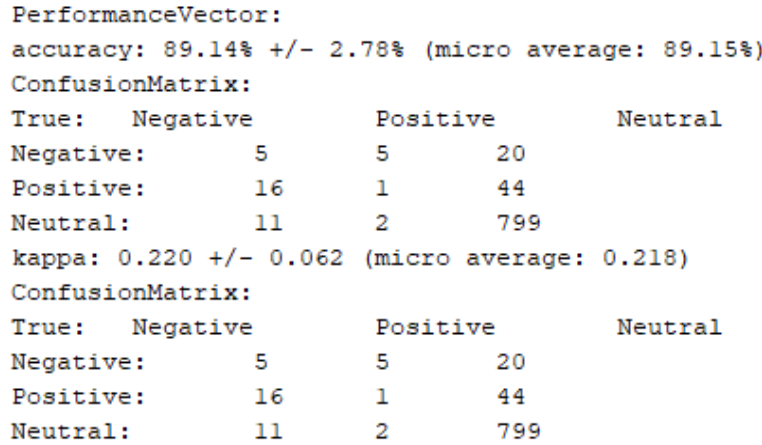

Gambar 22. Performance Vector Metode Naive Bayes

Performance vector sendiri merupakan bentuk deskripsi dari tabel hasil analisis. Hanya saya terdapat tambahan seperti kappa pada performance vector metode Naïve Bayes ini.

\section{Kesimpulan}

Tujuan dari penelitian yang dilakukan ini adalah untuk mengetahui tingkat akurasi dari tiga metode berbeda diantaranya KNN, Decision Tree dan Naïve Bayes, dengan menggunakan tools RapidMiner. Tools yang dipakai oleh peneliti adalah Rapidminer versi 9.7.2 dimana dalam hal ini peneliti harus melakukan pengumpulan data dari media sosial twitter dengan menyambungkan tools RapidMiner ke dalam API Twitter. Dan kemudian melakukan pengolahan data seperti filtering, labeling, dan kemudian analisis untuk mengetahui tingkat akurasi dari masing-masing metode.

Dalam penelitian ini dapat diketahui bahwa metode KNN, Decision Tree, dan Naïve Bayes dapat digunakan dalam bidang data mining.

Analisis sentimen terhadap data Twitter mengenai layanan BPJS mencapai tingkat akurasi 96.01\%. Dimana class precision untuk pred. negative adalah $52.17 \%$, pred positive adalah $0.00 \%$, dan pred. neutral adalah $97.27 \%$ dalam metode KNN. Lalu tingkat akurasi mencapai 96.13\%. Dimana class precision untuk pred. negative adalah $55.00 \%$, pred positive adalah $0.00 \%$, dan pred. neutral adalah $97.28 \%$ dalam metode Decision Tree. Dan yang terakhir mencapai akurasi $89.14 \%$. Dimana class precision untuk pred. negative adalah $16.67 \%$, pred positive adalah $1.64 \%$, dan pred. neutral adalah $98.40 \%$ dengan metode Naïve Bayes.

Dalam penelitian ini, dapat diketahui bahwa metode Decision Tree adalah metode yang tingkat akurasinya lebih tinggi dibandingkan kedua metode lainnya dengan tingkat akurasi sebesar $96.13 \%$.

\section{Saran}

Pada penelitian selanjutnya disarankan beberapa hal yaitu:

a. Jumlah data yang digunakan diharapkan lebih banyak dari sebelumnya untuk meningkatkan pemberian informasi terhadap layanan BPJS dan agar dapat lebih meningkatkan keakuratan dari analisis yang dilakukan.

b. Disarankan untuk menggunakan metode lainnya sehingga dapat mengetahui berbagai macam metode lainnya.

\section{Daftar Pustaka}

Buntoro, G. A. (2017). Analisis Sentimen Calon Gubernur DKI Jakarta 2017 di Twitter. Journal of Information Technology, l(1), 32-41.

Cahyaningrum, N. I., Fatima, D. W. Y., Kusuma, W. A., Ramadhani, S. A., Destanto, M. R., \& Nooraeni, R. (2020). Analysis of User Sentiment of Twitter to Draft KUHP. Jurnal Matematika, Statistika Dan Komputasi, 16(3), 273. https://doi.org/10.20956/jmsk.v16i3.8239

Cahyanti, D., Rahmayani, A., \& Ainy, S. (2020). Analisis Performa Metode KNN Pada Dataset Pasien Pengidap Kanker Payudara. 1(2), 39-43.

Fitriyyah, S. N. J., Safriadi, N., \& Pratama, E. E. (2019). Analisis Sentimen Calon Presiden Indonesia 2019 dari Media Sosial Twitter Menggunakan Metode Naive Bayes. Jurnal Edukasi Dan Penelitian Informatika (JEPIN), 5(3), 279. https://doi.org/10.26418/jp.v5i3.34368

Linda, L., Haskas, Y., \& Kadrianti, E. (2020). Perbedaan Persepsi Pengguna Jasa BPJS Dan Non BPJS (Umum) Tentang Kualitas Pelayanan Keperawatan Dirsud Timika-Papua. 15.

Nurdin, A. D. (2017). Penerapan Data Mining Untuk Menganalisis Penjualan Barang Dengan Menggunakan Metode Apriori Pada Supermarket Sejahtera Lhokseumawe. Astika, D., Studi, P., Informatika, T., \& Malikussaleh, U., Vol. 6 No.

Sari, R. (2020). Analisis Sentimen Pada Review Objek Wisata Dunia Fantasi Menggunakan Algoritma KNearest Neighbor (K-Nn). EVOLUSI: Jurnal Sains Dan Manajemen, 8(1), 10-17. https://doi.org/10.31294/evolusi.v8i1.7371

Sarimuddin, S., Sari, J. Y., Mail, M., Masalu, M. A., Aristika, R. S., \& Nurfagra, N. (2020). Klasifikasi Data Aging Tunggakan Nasabah Menggunakan Metode Decision Tree Pada ULaMM Unit Kolaka. INFORMAL: Informatics Journal, 5(1), 26. https://doi.org/10.19184/isj.v5i1.16964

Sinaga, L. M., Sawaluddin, \& Suwilo, S. (2020). Analysis of classification and Naïve Bayes algorithm k-nearest neighbor in data mining. IOP Conference Series: Materials Science and 
Engineering, $725(1)$.

https://doi.org/10.1088/1757-899X/725/1/012106

Utami, I. (2020). Analisis Sistem Informasi Banjir Berbasis Media Twitter. 9(1), 67-72.

Zhang, W., Chen, X., Liu, Y., \& Xi, Q. (2020). A Distributed Storage and Computation k-Nearest Neighbor Algorithm Based Cloud-Edge
Computing for Cyber-Physical-Social Systems. IEEE Access, 8, 50118-50130. https://doi.org/10.1109/ACCESS.2020.2974764 